\title{
Performance of Islamic Political Parties in Indonesian Contemporary Political Practices
}

DOI: https://doi.org/10.47175/rissj.v3i1.397

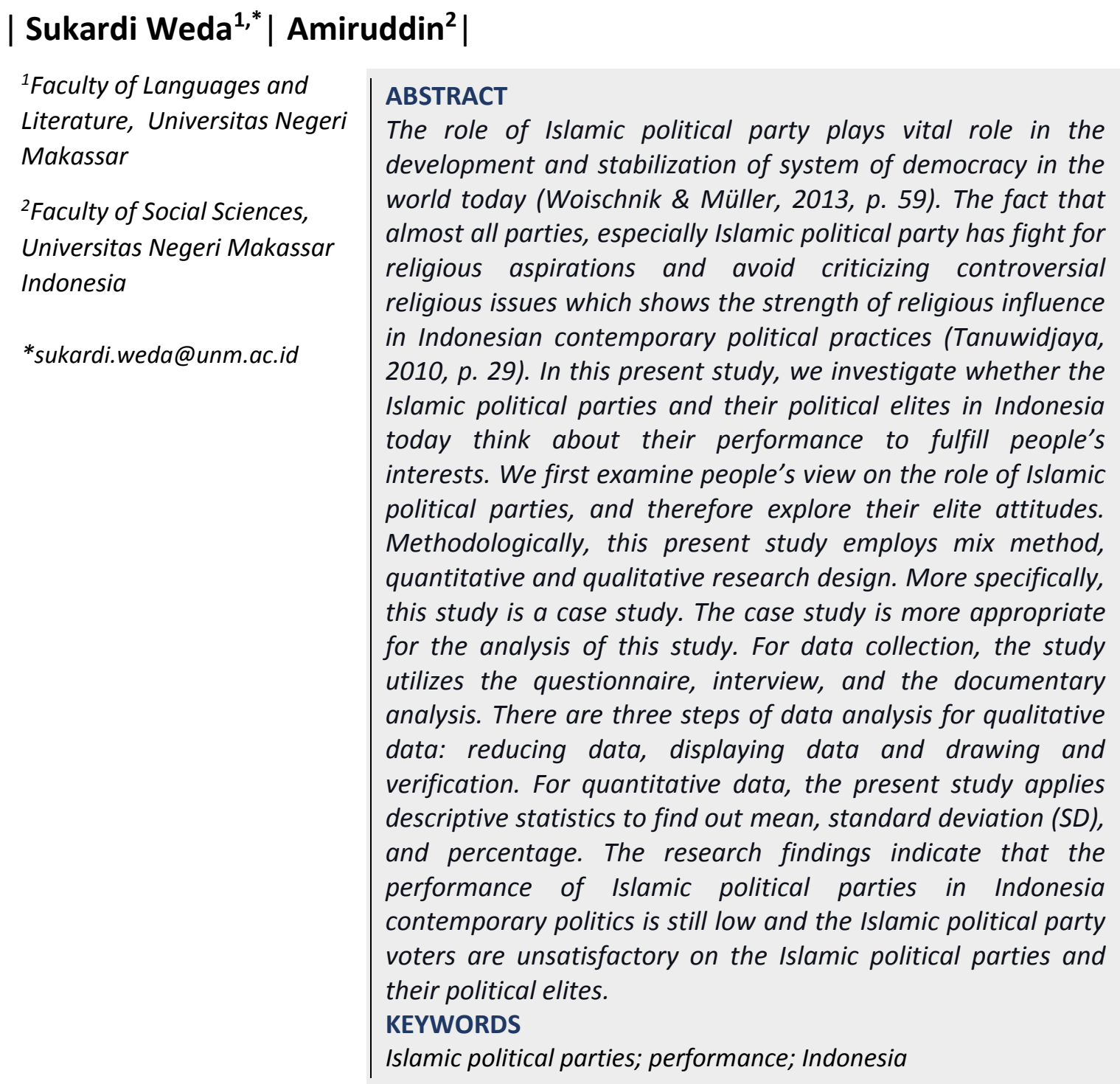

\section{INTRODUCTION}

In terms of history, since the declaration of Indonesian independence, multiparty systems are something that is natural in Indonesian society. Recorded in the political history of Indonesia, the most democratic elections took place in 1955. As a consequence of the adoption of a multi-party system, the 1955 elections accommodated 172 parties and organizations. However, in the 1955 elections only four political parties had the dominant vote, namely: [1] PNI as much as 22 percent, [2] Masyumi 20 percent, [3] Nahdhatul Ulama 18 percent, and [4] PKI 16 percent (Siddharth Chandra and Douglas Kammen cited in Mikail, 2015, p. 109).

In the New Order era, party power tried to consolidate himself, the rehabilitation of the disbanded Masyumi was rejected by the Sueharto regime. Political engineering, the politics of the New Order regime did not provide opportunity for Islamic political forces to rise again. 1973 forced functions were carried out and the Islamic parties joined the PPP 
(United Development Party). In 1985, the principle of Islamic PPP was forced to be replaced with Pancasila, because single principle policy (Miriam Budiajo as cited in Fajri, 2018, p. 5).

After the fall of the New Order regime in 1998, the government of the Republic of Indonesia in the reform era provided opportunities for citizens to establish political parties. A number of political parties were established by elites. Some elites from a variety of background, like civil society, Islamic scholar, Kyai from Pesantren established Islamic political parties. This is because, Islam still plays an important role, in Indonesian political practices (Tanuwidjaya, 2010, p. 29). At the beginning of the reform order, a number of Islamic political parties were also founded by a number of Islamic leaders, such as PKS, PBB, PKB, PPP, and others. As an Islamic political party with an adopted Islamic ideology, some people have hopes of these Islamic parties. But along with the progress of reforms, the performance of Islamic political parties has decreased, namely some elites from political parties are only pursuing power rather than fighting for the interests of the people. The reforms in the 1998 were to put fundamental policy for multiparty democracy to be realized with the Indonesia's first democratically contested general elections in 44 years (Porter, 2005, p. 215).

The lifting of party restrictions marks a new phenomenon of 'wild growth' of democracy, along with the proliferation of new parties. Many parties were formed on the basis of old affiliations or sects - primordial/communal sectarian loyalties long suppressed by Suharto's New Order regime - with the birth of Islamic, Christian, nationalist, socialist, Sukarnoist and other parties (Porter, 2005, p. 216).

According to the official website of Komisi Pemilihan Umum or the General Election Commission of the Republic of Indonesia, in the 1999 election the Islamic parties gained 34.2 percent of the vote, then in the 2004 Election it increased to 43.27 percent of the vote. However, in the 2009 elections the number of votes for Islamic parties dropped to 30 percent. Whereas, in the 2014 election, five Islamic based parties were only able to get 31.41 percent (Pratama, 2018).

The declining electoral influence of Islamic parties should be interpreted not as a decline in political Islam, but on the contrary: Islam has penetrated the dominant nationalist, secular, and Pancasila political parties and has made them stronger in their contests against Islamic parties, which do not. again become the only channel of Islamic aspirations (Tanuwidjaya, 2010, p. 29).

Therefore, Tanuwidjaya (2010, p. 29) argues that although Islamic parties gained around 44 percent of the national vote in the post-New Order 1955 elections, their electoral appeal has decreased. In 1999, Islamic parties garnered 36.3 percent of the vote, while in 2004 they received 41 percent. But in 2009, their support fell significantly to 29.2 percent, the worst electoral performance by Islamic parties since independence.

Indonesia's political excursion from time to time can never be separated from the political role played by Muslims, in its history, Indonesian Muslims have contributed greatly to the practices of political development and democracy. The participation of Muslims in political arena has made the national political stage move quite dynamically (Argenti \& Rifai, 2015, p. 7). This study aims at exploring the people's perception on the performance and practice of Islamic political parties in Indonesia contemporary society. The study therefore addresses two research questions.

The research questions of the study are: 1) Do Islamic political parties have good performance?, and 2) Do Islamic political party elites care on people's interest? 


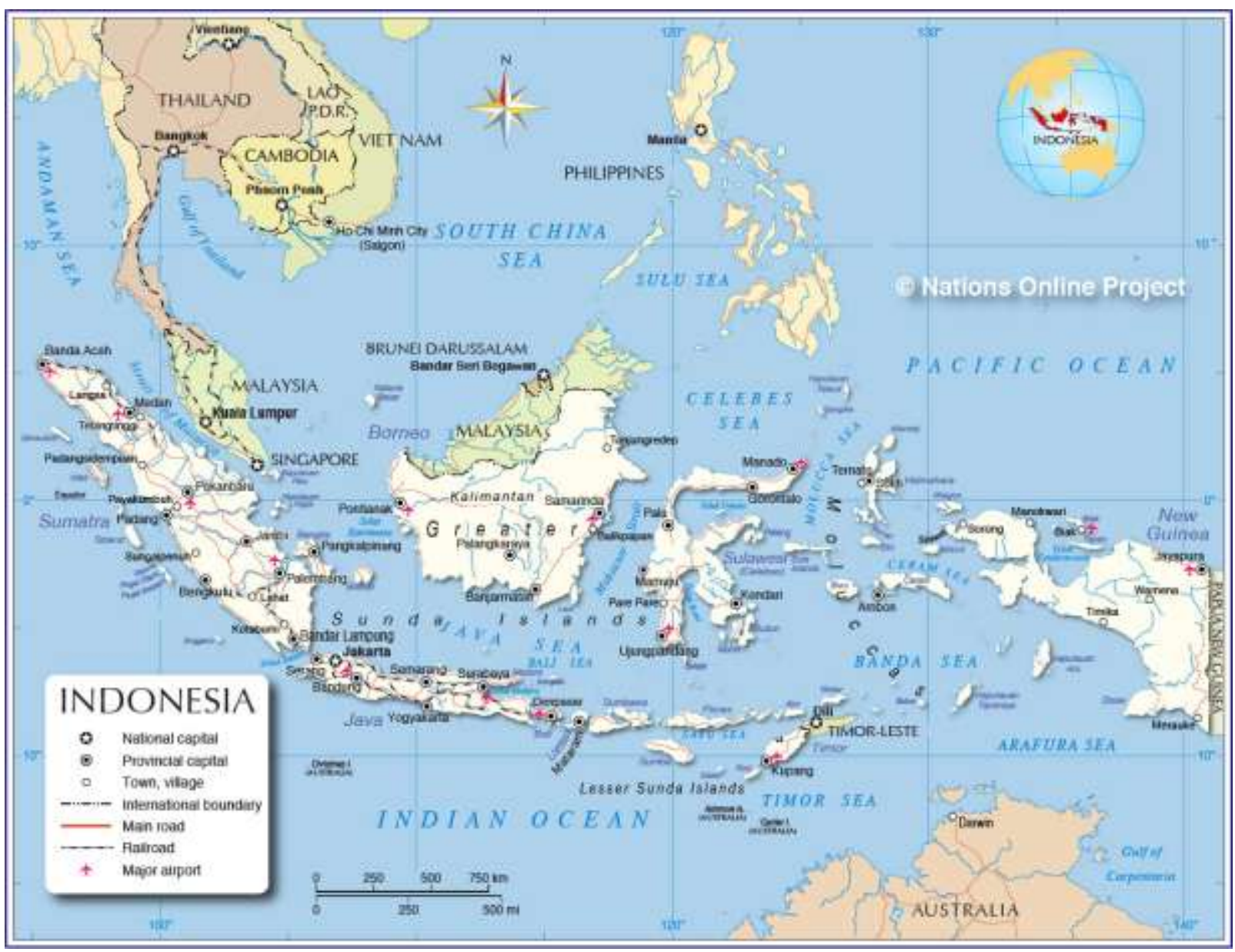

Map 1. Political Map of the Republic of Indonesia

(Source: https://www.nationsonline.org/oneworld/map/indonesia_map2.htm)

\section{LITERATURE REVIEW}

\section{Political parties in Indonesia}

In the first relatively free and fair general elections of 1955, the Islamic parties Masyumi, Nahdlatul Ulama (NU) and other minor parties accounted for nearly $45 \%$ of the vote (Miichi, 2015, p. 127). Miiche therefore argues that the five elections during the Suharto era were not considered to reflect Islamic aspirations because Masjumi was banned in 1960 and all Islamic parties were integrated as the United Development Party (PPP) in 1973.

In New Order Era, under Suharto's leadership as the second president of the Indonesian republic was brought to power for 32 years, political parties other than Golkar, namely PPP and PDI were marginalized and both parties always suffered losses. For reasons of corruption, collusion and nepotism, people power overthrew the Suharto regime in 1998, and the reform order was established.

At the beginning of the reform era in the 1999 general election, there were 48 parties competed in the election. Mahrus Irsyam and Lili Romli as cited in Weda (2015, p. 341) report that there were 48 political parties participating in the 1999 election, even 148 political parties who registered in the KPU in the 1999 elections, and only 48 political parties passed as election contestants, 99 of them were unable to take part in the 1999 elections, and 7 political parties that did not fulfill registration (administrative) requirements, even the number of political parties in Indonesia has reached 225 in late 2002. 
The 48 parties competed in 1999 general election in Indonesia in the beginning of reform era are: Partai Indonesia Baru, Partai Kristen Nasional Indonesia, PNI - Supeni, Partai Aliansi Demokrat Indonesia, Partai Kebangkitan Muslim Indonesia, Partai Ummat Islam, Partai Kebangkitan Ummat, Partai Masyumi Baru, Partai Persatuan Pembangunan, Partai Syarikat Islam Indonesia, PDI Perjuangan, Partai Abul Yatama, Partai Kebangsaan Merdeka, Partai Demokrasi Kasih Bangsa, PAN, Partai Rakyat Demokrat, Partai Syarikat Islam Indonesia - 1905, Partai Katolik Indonesia, Partai Rakyat Indonesia, Partai Politik Islam Indonesia Masyumi, PBB, Partai Solidaritas Pekerja Seluruh Indonesia, Partai Keadilan, Partai Nahdlatul Ummat, PNI - Front Marhaenis, Partai Ikatan Penerus Kemerdekaan Indonesia, Partai Republik, Partai Islam Demokrat, PNI Massa Marhaen, Partai Musyawarah Rakyat Banyak, Partai Demokrasi Indonesia, Partai Golkar, Partai Persatuan, PKB, Partai Uni Demokrasi Indonesia, Partai Buruh Nasional, Partai MKGR, Partai Daulat Rakyat, Partai Cinta Damai, Partai Keadilan dan Persatuan, Partai Solidaritas Pekerja, Partai Nasional Bangsa Indonesia, Partai Bhinneka Tunggal Ika Indonesia, Partai Solidaritas Uni Nasional Indonesia, Partai Nasional Demokrat, Partai Ummat Muslimin Indonesia, dan Partai Pekerja Indonesia. Of the 48 political parties in 1999 general election, there were 19 religious-affiliated parties, and 17 of them were Islamic political parties and 2 of them were non-Islamic political parties.

In the 2004 election, there were 24 political parties competed in the general election. Those political parties are: PDI-P, PPP, PKB, Golkar, PAN, PBB, PKS, Partai Nasional Indonesia Marhaenisme, Partai Buruh Sosial Demokrat, Partai Merdeka, Partai Persatuan Demokrasi Kebangsaan, Partai Perhimpunan Indonesia Baru, Partai Nasional Banteng Kemerdekaan, Partai Keadilan dan Persatuan Indonesia, Partai Penegak Demokrasi Indonesia, Partai Persatuan Nahdlatul Ummah Indonesia, Partai Karya Peduli Bangsa, Partai Bintang Reformasi, Partai Damai Sejahtera, Partai Patriot Pancasila, Partai Sarikat Indonesia, Partai Persatuan Daerah, Partai Pelopor. Of the 24 political parties in 2004, there were 8 religious parties, 7 are Islamic parties and 1 is non-Islamic party.

In the 2009 election, there were 40 political parties competed in the general election. Those parties are: Partai Barisan Nasional, Partai Demokrasi Pembaruan, Partai Gerakan Indonesia Raya (Gerindra), Partai Hanura, Partai Indonesia Sejahtera, Partai Karya Perjuangan, Partai Kasih Demokrasi Indonesia, Partai Kebangkitan Nasional Ulama, Partai Kedaulatan, Partai Matahari Bangsa, Partai Nasional Benteng Kerakyatan, Partai Patriot, Partai Peduli Rakyat Nasional, Partai Pemuda Indonesia, Partai Pengusaha dan Pekerja Indonesia, Partai Perjuangan Indonesia Baru, Partai Persatuan Daerah, Partai Republik Nusantara, Partai Amanat Nasional (PAN), Partai Bintang Reformasi (PBR), Partai Bulan Bintang (PBB), Partai Damai Sejahtera (PDS), Partai Demokrasi Indonesia Perjuangan (PDIP), Partai Demokrasi Kebangsaan (PDK), Partai Demokrat, Partai Golongan Karya (Partai Golkar), Partai Karya Peduli Bangsa (PKPB), Partai Keadilan dan Persatuan Indonesia (PKPI), Partai Keadilan Sejahtera (PKS), Partai Kebangkitan Bangsa (PKB), Partai Nasional Indonesia (PNI) Marhaenisme, Partai Pelopor, Partai Penegak Demokrasi Indonesia (PPDI), Partai Persatuan Pembangunan (PPP), Partai Aceh, Partai Aceh Aman Sejahtera, Partai Bersatu Aceh, Partai Daulat Aceh, Partai Rakyat Aceh, dan Partai Suara Independen Rakyat Aceh.

In the 2014 general election, there were 12 political parties competed in the election. Those parties are: PDI-P, Golkar, Demokrat, PKB, PPP, PAN, PKS, Gerindra, Hanura, Nasdem, PBB, dan PKPI. From those election contestant, there were 5 Islamic political parties (Kompas.com). 


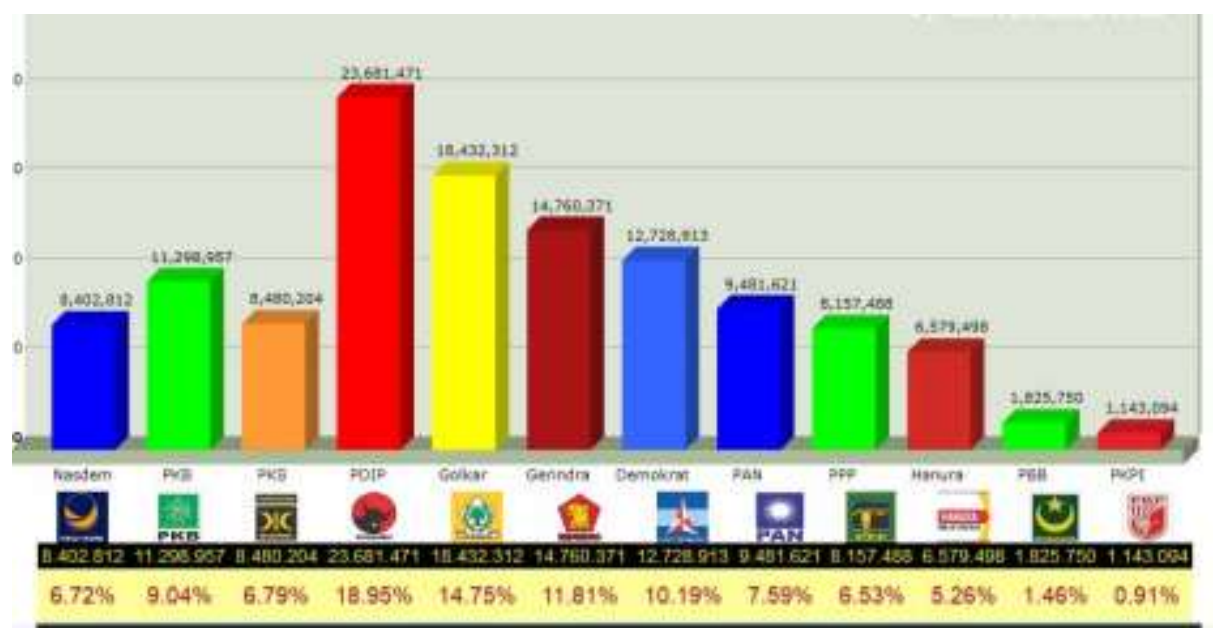

Graph 1. Results of the 2014 Election in Indonesia (Source: http://aswandi.or.id/2014/05/13/grafik-hasil-pemilu-2014/)

In the 2014 election, there were 5 Islamic political parties participating in the fight to place their legislative candidates. Of the 5 Islamic political parties, none of the Islamic political parties can win above 10 percent. Consequently, National Awakening Party (PKB) was able to get $9.04 \%$ of the votes, followed by National Mandate Party (PAN) with $7.59 \%$ of the votes, Prosperous Justice Party (PKS) with $6.79 \%$ of the votes, the United Development Party (PPP) with $6.53 \%$ of the votes, and the last position was UN with $1.46 \%$. This shows that Islamic political parties are unable to compete with nationalist ideological parties, such as the Indonesian Democratic Party Struggle (PDIP) with $18.95 \%$ of the vote, followed by Golkar party with $14.75 \%$ of votes, Gerindra party, with $11.81 \%$ of the votes, and Demokrat party with $10.19 \%$ of the votes. Data on the vote of Islamic parties in elections in Indonesia from 1955 to 2014 is a factual record of how Indonesian Muslims actualize Islamic teachings in political agenda (Hamdan, 2003, p. 34).

Tanuwidjaya (2010, p. 30) provides information on four democratic elections in Indonesia which reveals that Islamic political parties fail to win more than 44 percent of the vote despite the fact that 80 to 90 percent of Indonesia's population is Muslim as listed in table 1 . He therefore adds that although Islamic parties gained around 44 percent of the national vote in the 1955 post-New Order or reform elections, their electoral appeal has declined. In 1999, Islamic parties garnered 36.3 percent of the vote, while in 2004 they received 41 percent. In 2009, their support fell significantly to 29.2 percent, the worst electoral performance by Islamic parties since independence.

Table 1. Results of Post Suharto Legislative Elections (\% share of vote)

\begin{tabular}{|l|c|c|c|c|}
\hline \multirow{2}{*}{ Political Party } & \multicolumn{4}{|c|}{ Year of Elections } \\
\cline { 2 - 5 } & 1999 & 2004 & 2009 & 2014 \\
\hline PK/PKS & 1.36 & 7.34 & 7.88 & 6.79 \\
\hline PAN & 7.12 & 6.44 & 6.01 & 7.59 \\
\hline PPP & 10.72 & 8.15 & 5.32 & 6.53 \\
\hline PKB & 12.62 & 10.57 & 4.94 & 9.04 \\
\hline PBB & 1.94 & 2.62 & 1.79 & 1.46 \\
\hline
\end{tabular}

Source: Tanuwidjaya (2010, p. 34) \& http://aswandi.or.id/2014 


\section{Islamic Political Parties in Indonesia Contemporary Political Practices}

Indonesia is the fourth largest country in the world after China, the United States and India. Indonesia is the largest Muslim country in the world and 88 percent of its approximately 240 million population claim to be Muslim (Woischnik \& Müller, 2013, p. 60). Indonesia is a very large and diverse Southeast Asian country with a population of around 240 million people. It is the most populous Muslim country in the world (Woodward, 2008, p. 44). Despite the fact that around 90 percent of Indonesia's population is Muslim, Islamic parties in the country have struggled to gain broad popular support (Tomsa, 2012, p. 486). Indonesia's democratic transition in the late 1990s led to the formation of many political parties, many of which were religious parties (Woodward, 2008, p. 41).

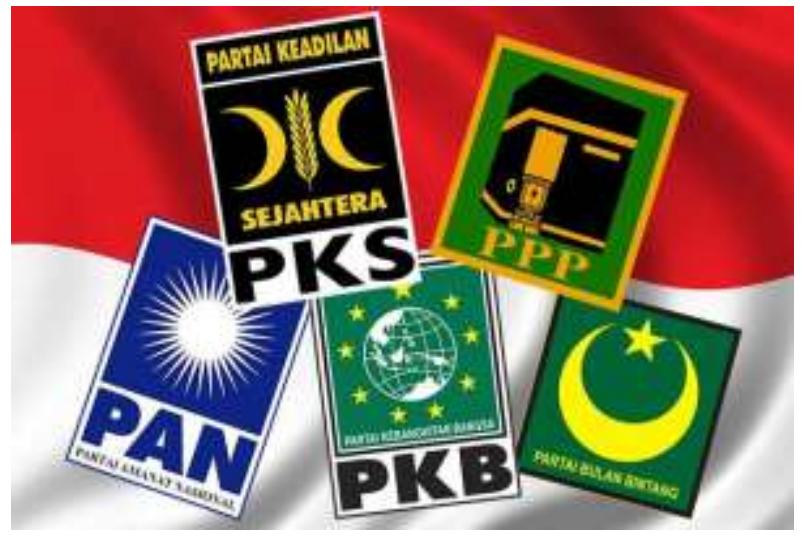

Picture 1. 5 Islamic Political Parties in Indonesia in 2014 and 2019 Legislative Election (Source: https://merahputih.com/post/read/mengapa-partai-islam-tak-pernah-menang)

Muhammadiyah, NU, and other Islamic organizations joined the Masyumi party, which was founded in 1945, after the proclamation of independence (17 August), to represent Muslim interests in competition with the newly formed parties, notably the Indonesian National Party (PNI) (Porter) ., 2005, p.40). Suharto had worked carefully, step by step, to simplify the party system and force them to reduce their numbers. In 1973, the Islamic parties, NU, Perti (Islamic Education Association), Parmusi and PSII were merged into the United Development Party (PPP). Since then, PPP has become part of the Golkar system (plus-two parties) as a very unequal and unreliable development partner. NU became the dominant element of PPP (Porter, 2005, p. 43).

\section{Previous Studies on Islamic Political Parties in Indonesia}

Many scholars have conducted research on Islamic political parties in Indonesia contemporary politics. Some of those scholars are as revealed in Table 2.

Table 2. Studies on Islamic (Religious) Political Parties in Indonesia

\begin{tabular}{|c|c|l|l|}
\hline Author(s) & Year & \multicolumn{1}{|c|}{ Title } & \multicolumn{1}{c|}{ Results } \\
\hline Sunny Tanuwidjaya & 2010 & $\begin{array}{l}\text { Political Islam and } \\
\text { Islamic Parties in } \\
\text { Indonesia: Critically } \\
\text { Assessing the Evidence } \\
\text { of Islam's Political } \\
\text { Decline }\end{array}$ & $\begin{array}{l}\text { The declining electoral influence of } \\
\text { Islamic parties should be interpreted } \\
\text { not as a decline in political Islam, but } \\
\text { rather the opposite: Islam has } \\
\text { penetrated the dominant, secular, } \\
\text { Pancasila-based nationalist political } \\
\text { parties and has made them stronger in } \\
\text { their contests against Islamic parties, } \\
\text { which no. again became the only }\end{array}$ \\
\hline
\end{tabular}




\begin{tabular}{|c|c|c|c|}
\hline & & & $\begin{array}{l}\text { channel of Islamic aspirations. The fact } \\
\text { that almost all parties have } \\
\text { accommodated religious aspirations } \\
\text { and avoided criticism of controversial } \\
\text { religious issues shows the power of } \\
\text { religion's influence in Indonesian } \\
\text { politics today (Sunny Tanuwidjaya, } \\
2010,29 \text { ). }\end{array}$ \\
\hline Kerem Kilicdaroglu & 2015 & $\begin{array}{l}\text { The Success and } \\
\text { Failure of Islamic } \\
\text { parties in Indonesia } \\
\text { and Turkey }\end{array}$ & $\begin{array}{l}\text { In Indonesia, Islamic parties are } \\
\text { diverse and rather than representing } \\
\text { the whole Muslim population, they } \\
\text { represent limited group of people or } \\
\text { organization. Islamic concerns } \\
\text { come forward in these parties and } \\
\text { economic, social policies are } \\
\text { secondary. Furthermore, because they } \\
\text { represent different levels of Islam, } \\
\text { they are supported by Islamic } \\
\text { organizations, even by the most } \\
\text { radical ones, which damages the } \\
\text { image of Islamic parties and } \\
\text { sometimes they are considered as a } \\
\text { threat to democracy. Secular parties } \\
\text { also use Islamic rhetoric in political } \\
\text { campaigns and pass laws to satisfy } \\
\text { the Islamists, and it limits the political } \\
\text { area of Islamic parties. Diversity } \\
\text { within the Islamic parties decreases } \\
\text { chance of aggregation (Kerem } \\
\text { Kilicdaroglu, 2015, p. 27). }\end{array}$ \\
\hline $\begin{array}{l}\text { Jan Woischnik \& } \\
\text { Philipp Müller }\end{array}$ & 2013 & $\begin{array}{l}\text { Islamic Parties and } \\
\text { Democracy in } \\
\text { Indonesia: Insight from } \\
\text { the World's Largest } \\
\text { Muslim Country }\end{array}$ & $\begin{array}{l}\text { Islamic parties do have the potential } \\
\text { to transform, slowly but surely, into } \\
\text { democratic-friendly political actors } \\
\text { and take responsibility for democratic } \\
\text { institutions. As the examples of } \\
\text { parties in Indonesia show, the } \\
\text { possibility of an initially unexpected } \\
\text { programmatic and ideological } \\
\text { transformation after the establishment } \\
\text { of a democratic system of government } \\
\text { cannot be ruled out. With this in } \\
\text { mind, one should not refuse contact } \\
\text { with Islamic parties that are } \\
\text { inherently tolerant and open to } \\
\text { democratic principles, but instead } \\
\text { actively seek partners in the field of } \\
\text { party cooperation and commit to } \\
\text { long-term democratic values (Jan } \\
\text { Woischnik \& Philipp) . Müller, } 13 \text {, } \\
\text { (pp. } 78-79 \text { ). }\end{array}$ \\
\hline Mark Woodward & 2008 & $\begin{array}{l}\text { Indonesia's Religious } \\
\text { Political Parties: } \\
\text { Democratic } \\
\text { Consolidation and }\end{array}$ & $\begin{array}{l}\text { Only Islamic parties are politically } \\
\text { significant. It is possible to } \\
\text { distinguish two basic types of } \\
\text { religious parties. Some are based on }\end{array}$ \\
\hline
\end{tabular}




\begin{tabular}{|l|l|l|}
\hline \multirow{5}{*}{} & $\begin{array}{l}\text { Security in Post-New } \\
\text { Order Indonesia }\end{array}$ & $\begin{array}{l}\text { explicitly religious principles; others } \\
\text { are nominally secular but are led by } \\
\text { religious leaders or attract a particular } \\
\text { religious community. While } \\
\text { Indonesia is predominantly Muslim, } \\
\text { Islamic parties have had only limited } \\
\text { appeal. The openness of the political } \\
\text { system and the ability of smaller } \\
\text { parties to enter coalitions have given } \\
\text { their leaders access to office and } \\
\text { patronage (Mark Woodward, 2008, p. } \\
\text { 41). }\end{array}$ \\
\hline
\end{tabular}

\section{RESEARCH METHODS}

In order to answer the research questions of this study, questionnaires were distributed to respondents from undergraduate program, graduate program, academics, and civil servant, at the Faculty of Social Sciences Universitas Negeri Makassar, Indonesia. Other data of this study were obtained from interview. The data from interview were intended to support the data from questionnaire. This study therefore applies a mixed-methods design through the analysis of questionnaire and interview.

\section{Research Design}

Methodologically, this present study employs mix method, qualitative and quantitative research design. More specifically, the case study is more appropriate for its analysis. For data collection, the study utilizes the questionnaire, in-depth interview, and the documentary analysis. There are three steps of data analysis for qualitative data: reducing data, displaying data and drawing and verification. For quantitative data, the present study applies descriptive statistics to see mean, standard deviation (SD), and percentage. Additionally, the study aims to explore the people's perception on Islamic political parties' performance and contribution in Indonesia contemporary political era.

\section{Participants}

There were 65 participants to respond the questionnaire and 22 informants to give valuable information in this present study. They were 38 or $58.46 \%$ male and 27 or $41.54 \%$ female as revealed in Graph 2. The participants were ranging from $21-60$ years old. The participants were the stakeholders of the Faculty of Social Sciences of State University of Makassar, Indonesia.

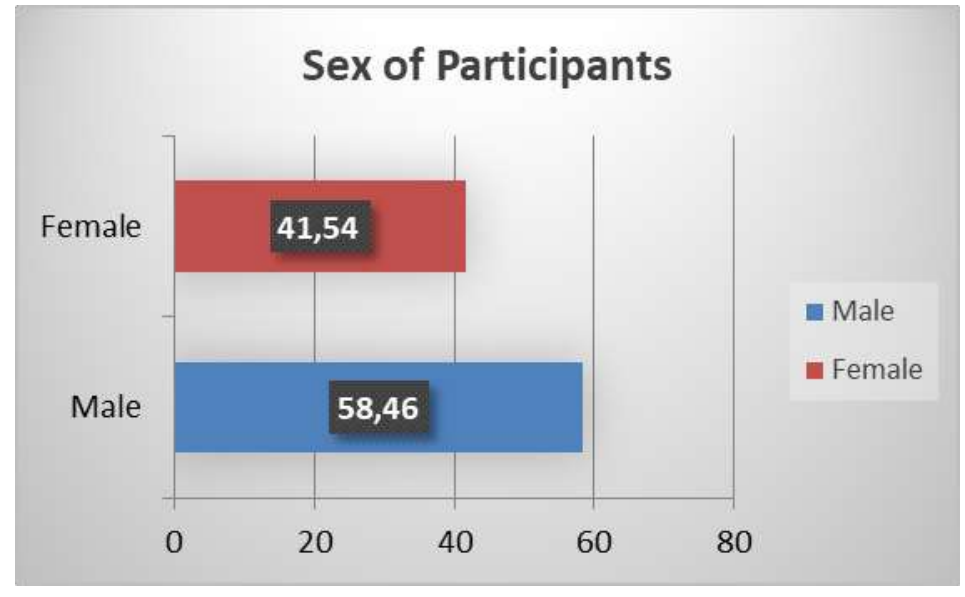

Graph 2. Sex of Participants 


\section{Instrument and Procedure}

The instruments used to assess the peoples' perception on performance of Islamic political parties in Indonesia contemporary politics were questionnaire and interview. The data of the study were collected in December 2018 at the Faculty of Social Sciences Universitas Negeri Makassar in 2018/2019 academic year. The participants were asked to fill in the questionnaire and respond the interview asking the Islamic political party practices in Indonesia contemporary politics.

\section{Data Analysis}

The data obtained through questionnaire were analyzed using Statistical Package of Social Sciences (SPSS) Statistics 9.0 which showed the mean, Standard Deviation (SD), and percentage. The weight and rank are also revealed in the study. The data obtained from the interview were coded and analyzed to find out the answers toward questions as previously stated.

\section{RESULTS AND DISCUSSION}

In this section of the study, we present the results and discussions as confirmation rate of the research questions as previously stated.

\section{Demographic Information of Participants}

There were 65 students participated in this study to examine their perceptions on performance of Islamic political parties in Indonesian contemporary political practices. The students were from faculty members of the Faculty of Social Sciences Universitas Negeri Makassar. Their educational background is undergraduate (24 or 36.92\%), master's degree ( 24 or $36.92 \%$ ), and doctoral degree (17 or $26.15 \%$ ). There were 38 or $58.46 \%$ female and there were 27 or $41.54 \%$ male. The participants' age ranged from 21 - above 50 years old. The participants were from a wide variety of jobs, there were 33 or $50.77 \%$ lecturers, there were 18 or $27.69 \%$ civil servants, and there were 14 or $21.53 \%$ students. The demographic profile of participants is revealed in detail in Table 1 as follows.

Table 1. Demographic Information of Participants

\begin{tabular}{|c|c|c|c|}
\hline \multicolumn{2}{|c|}{ Demographic Information } & \multirow[t]{2}{*}{ Frequency } & \multirow[t]{2}{*}{ Percentage } \\
\hline Gender & & & \\
\hline & 1. Female & 38 & 58.46 \\
\hline & 2. Male & 27 & 41.54 \\
\hline \multicolumn{4}{|l|}{ Age } \\
\hline & 1. $21-30$ & 21 & 32.30 \\
\hline & 2. $31-40$ & 18 & 27.69 \\
\hline & 3. $41-50$ & 21 & 32.30 \\
\hline & 4. $51>$ & 5 & 7.69 \\
\hline \multicolumn{4}{|c|}{ Education } \\
\hline & 1. Undergraduate & 24 & 36.92 \\
\hline & 2. Master's Degree & 24 & 36.92 \\
\hline & 3. Do toral Degree & 17 & 26.15 \\
\hline \multicolumn{4}{|l|}{ Job } \\
\hline & 1. Lecturer & 33 & 50.77 \\
\hline & 2. Civil Servant & 18 & 27.69 \\
\hline & 3. Students & 14 & 21.53 \\
\hline
\end{tabular}

Source: Own results 
People's Views on the Performance of Islamic Political Parties through Questionnaire In this section, we start by focusing on questions about the people's view on the performance of Islamic political parties and the elite attitudes of the Islamic parties. We asked people how many times they participated in general elections, the existence of Islamic political parties, the number of Islamic political parties in Indonesia contemporary society today, the parties' and elites' programs, and other related issues on ideal practices of a professional party.

The first question stated in the questionnaire of the study "How many times have you participated in legislative elections?. The answers of the question can be seen on Graph 3.

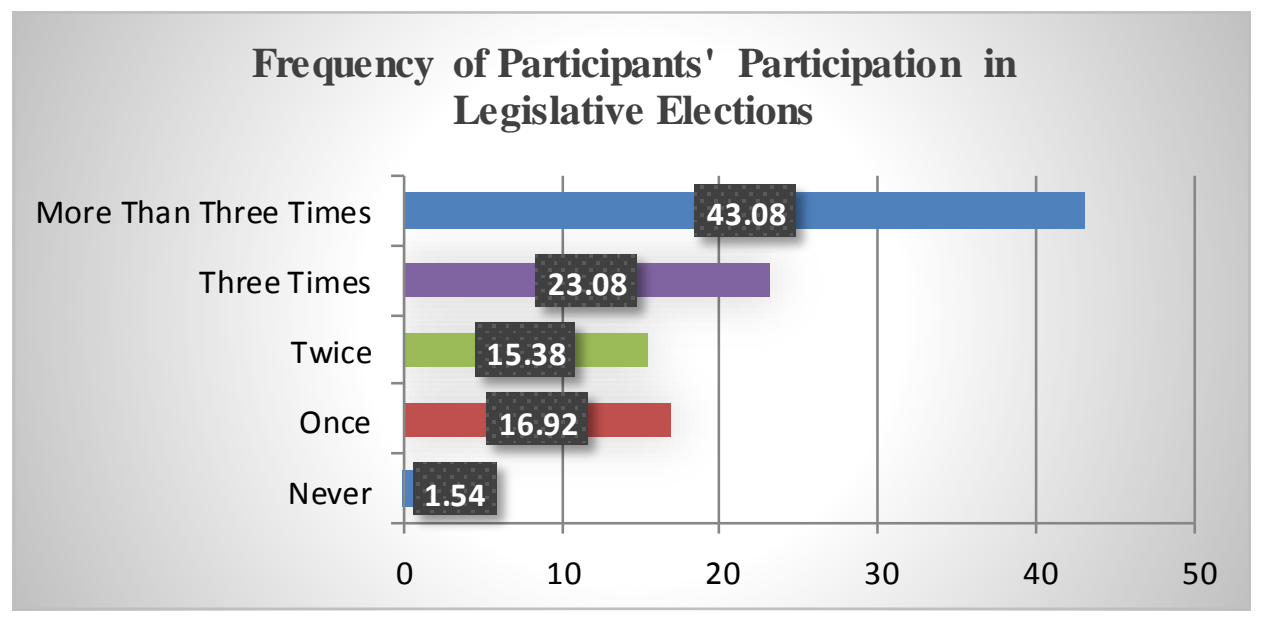

Graph 3. Following Legislative Elections

Graph 3 indicates that there was 1 or $1.54 \%$ of the participants stated that he has never participated in the legislative elections conducted in Indonesia. There were 11 or $16.92 \%$ of the participants responded that they have participated once in the legislative elections in Indonesia. There were 10 or $15.38 \%$ of the participants stated that they have participated in the legislative elections twice in Indonesia. There were 15 or 23.08 of the participants stated that they have participated in legislative elections three times and there were 28 or $43.08 \%$ of the participants said that they have participated more than three times in legislative elections in Indonesia contemporary politics.

The second question of the questionnaire "Have you participated in the 2014 legislative election in Indonesia?"

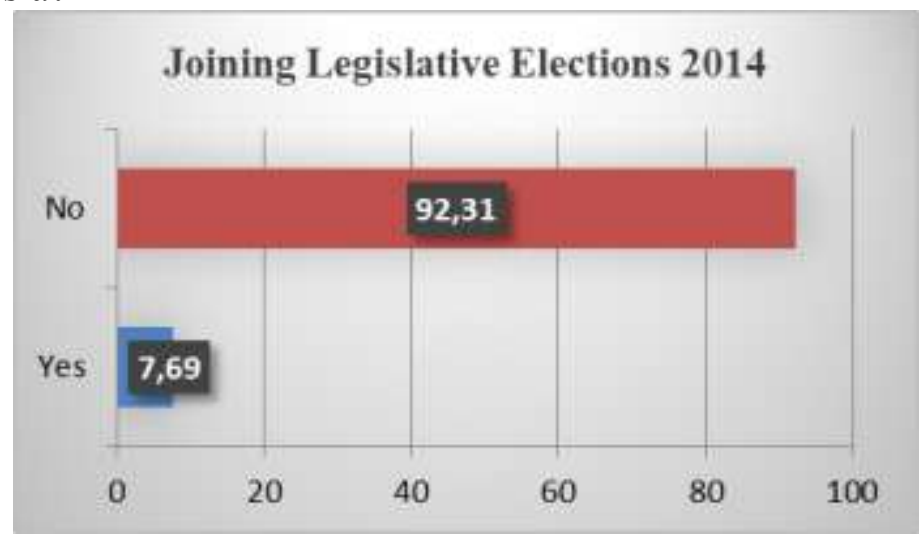

Graph 4. Joining Legislative Elections 2014 
The Graph 4 shows that there 5 or $7.69 \%$ of the participants have not joined the legislative election 2014 and there were $92.30 \%$ of them stated that they have joined the legislative election 2014.

The third question in the questionnaire was "Have you known Islamic political parties in Indonesia?"

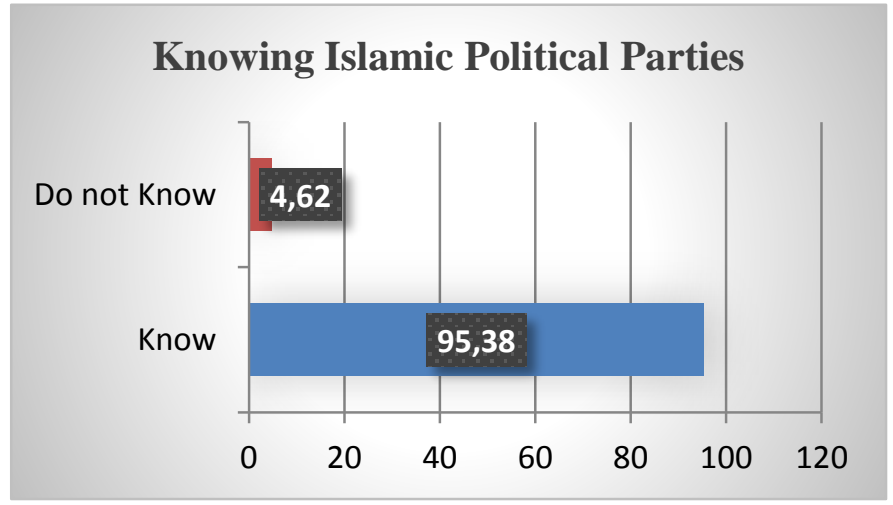

Graph 5. Knowing Islamic Political Parties

As revealed in Graph 5, there were 62 or $95.38 \%$ of the participants mentioned that they have known the Islamic political parties and there were only 3 or $4.62 \%$ of them stated that they have not known Islamic political parties in Indonesia.

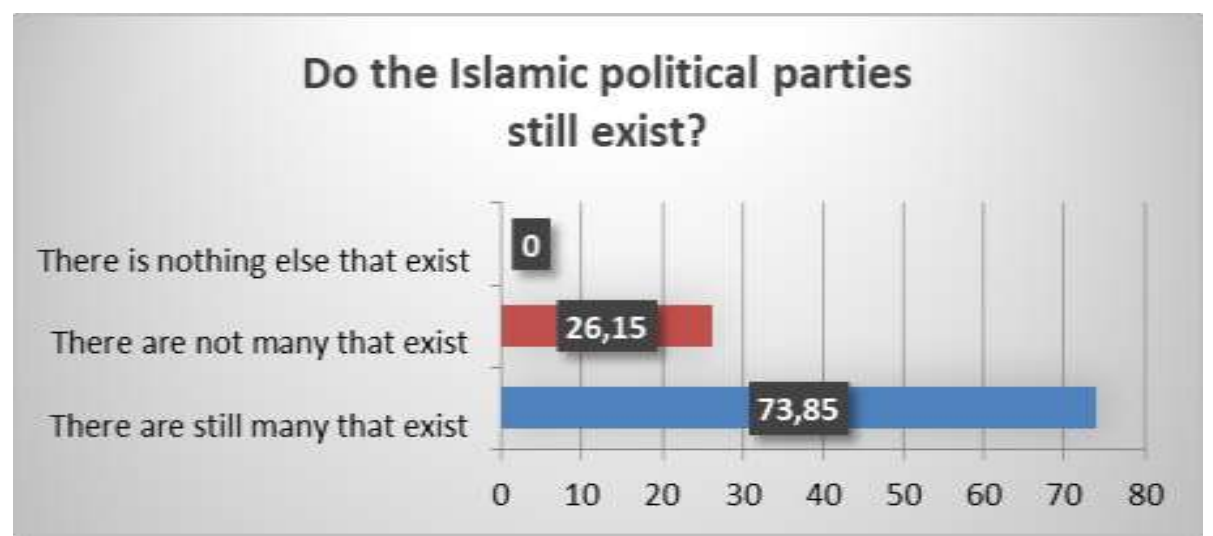

Graph 6. The Existence of Islamic Political Parties

Graph 6 indicates that there were 48 or $73.85 \%$ of the participants stated that there are still many Islamic political parties exist in Indonesia and there were 17 or $26.15 \%$ of them mentioned that there are not many Islamic political parties exist in Indonesia contemporary politics. None of the participants stated that Islamic political parties do not exist anymore in Indonesia.

Question number 5 of the questionnaire "Mention the Islamic political parties in Indonesia today?. For question number 5, the participants may choose more than 1 choices, and there were 221 answers of this question. 


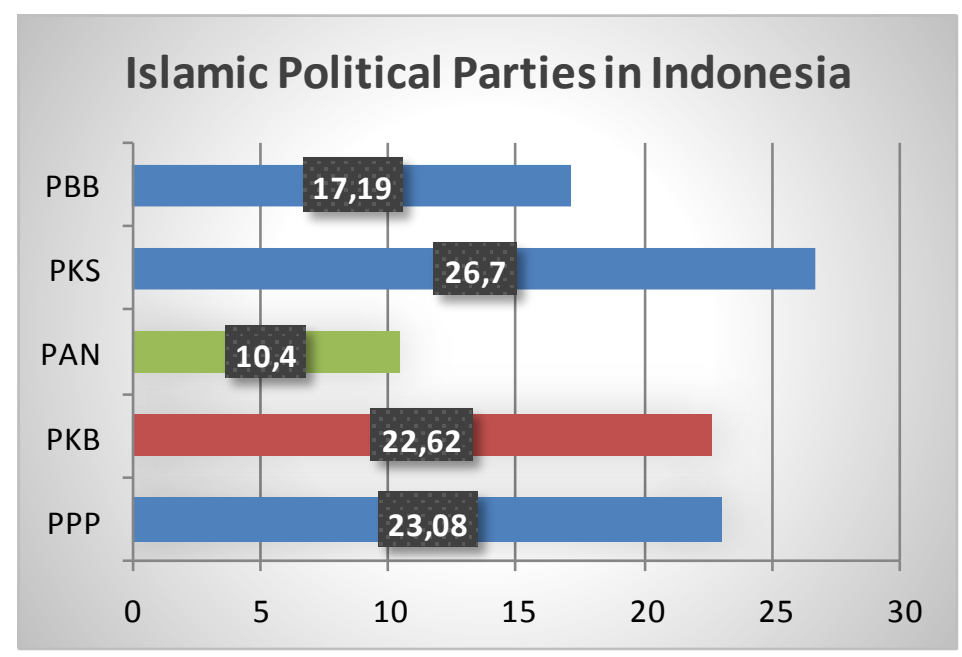

Graph 7. Islamic Political Parties in Indonesia

As indicated in Graph 7 that there were 51 or $23.08 \%$ answers revealed that they mentioned the United Development Party (PPP). There were 50 or $22.62 \%$ answers indicated that the participants mentioned National Awakening Party (PKB). There were 23 or $10.4 \%$ answers revealed that the participants mentioned National Mandate Party (PAN). There were 59 or $26.7 \%$ of answers showed that the participants mentioned Prosperous Justice Party (PKS) and there were 38 or $17.19 \%$ answers stated that the participants mentioned Bulan Bintang Party (PBB).

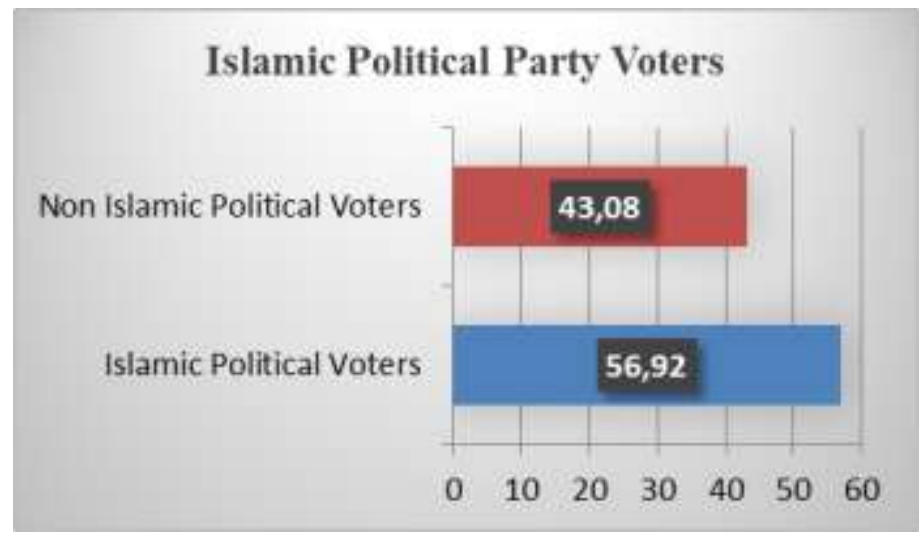

Graph 8. Islamic Political Party Voters

Graph 8 indicated that there were 28 or $43.08 \%$ non-Islamic political party voters and there were 28 or $56.92 \%$ of the participants were Islamic political party voters in legislative election 2014.

Table 2. Legislative Election Message Socialization by General Election Commission

\begin{tabular}{|l|c|c|c|c|c|c|c|}
\hline \multicolumn{1}{|c|}{$\mathrm{N}=65$} & $\begin{array}{c}\text { Do not } \\
\text { Understand }\end{array}$ & $\begin{array}{c}\text { Quite } \\
\text { Understand }\end{array}$ & Understand & $\begin{array}{c}\text { Strongly } \\
\text { Understand }\end{array}$ & Mean & SD & Weight \\
\hline $\begin{array}{l}\text { To what extent } \\
\text { the socialization } \\
\text { message of }\end{array}$ & 4.6 & 47.7 & 43.1 & 4.6 & 2.4769 & 2.4769 & 47.7 \\
$\begin{array}{l}\text { Islamic political } \\
\text { parties gave you }\end{array}$ & & & & & & & \\
\hline
\end{tabular}




\section{understanding about general election process from General Election Commission?}

The highest response of question 7 (In your opinion, to what extent of socialization message of legislative general election 2014 made by General Election Commission gave you understanding about general election process?.) was Quite Understand with $47.7 \%$ and the weight was $47.7 \%$ indicates that $47.7 \%$ of the respondents mentioned that the legislative election message socialization made by General Election Commission was understandable by voters.

Table 3. The Islamic Political Parties Assured the Program They Carried out

\begin{tabular}{|c|c|c|c|c|c|c|c|}
\hline $\mathrm{N}=65$ & $\begin{array}{l}\text { Unconvinc } \\
\text { ing } \\
\text { (1) }\end{array}$ & $\begin{array}{c}\text { Quite } \\
\text { convincing } \\
\text { (2) }\end{array}$ & $\begin{array}{c}\text { Convincing } \\
\text { (3) }\end{array}$ & $\begin{array}{c}\text { Very } \\
\text { convincing } \\
\text { (4) }\end{array}$ & Mean & $\mathrm{SD}$ & Weight \\
\hline $\begin{array}{l}\text { To what extent } \\
\text { do Islamic } \\
\text { political parties } \\
\text { convince you of } \\
\text { the program } \\
\text { being carried } \\
\text { out? }\end{array}$ & 21.5 & 50.8 & 26.2 & 1.5 & 2.0769 & .73544 & 78.3 \\
\hline
\end{tabular}

The highest response of question 8 (To what extent of Islamic political parties assured the program they carried out?.) was Quite Convincing with $50.8 \%$ and the weight was $78.3 \%$ indicates that $78.3 \%$ of the respondents mentioned that the Islamic political parties assured the program they carried out.

Table 4. The Islamic Political Parties Pro on the Interest of the People

\begin{tabular}{|l|c|c|c|c|c|c|c|}
\hline \multicolumn{1}{|c|}{$\mathrm{N}=65$} & $\begin{array}{c}\text { Very not pro- } \\
\text { people } \\
(1)\end{array}$ & $\begin{array}{c}\text { Not pro- } \\
\text { people } \\
(2)\end{array}$ & $\begin{array}{c}\text { Less pro- } \\
\text { people } \\
(3)\end{array}$ & $\begin{array}{c}\text { Pro-people } \\
(4)\end{array}$ & Mean & SD & Weight \\
\hline $\begin{array}{l}\text { In your opinion, } \\
\text { is the policy } \\
\text { taken by Islamic } \\
\text { political parties } \\
\text { pro on the } \\
\text { interests of the } \\
\text { people? }\end{array}$ & 3.1 & 6.26 .2 & 41.5 & 49.2 & 3.3692 & .74097 & 49.2 \\
\hline
\end{tabular}

The highest response of question 9 (In your opinion, is the policy taken by Islamic political parties pro on the interests of the people?.) was Pro People with $49.2 \%$ and the weight was $49.2 \%$ indicates that $47.7 \%$ of the respondents mentioned that the Islamic political parties pro on the interest of the people who voted them. 
Table 5. The Islamic Political Parties Care about the Interests of the People

\begin{tabular}{|l|c|c|c|c|c|c|c|}
\hline \multicolumn{1}{|c|}{$\mathrm{N}=65$} & $\begin{array}{c}\text { Do not } \\
\text { Care } \\
(1)\end{array}$ & $\begin{array}{c}\text { Less Care } \\
(2)\end{array}$ & $\begin{array}{c}\text { Care } \\
(3)\end{array}$ & $\begin{array}{c}\text { Very Care } \\
(4)\end{array}$ & Mean & SD & Weight \\
\hline $\begin{array}{l}\text { In your opinion, } \\
\text { after the party } \\
\text { members sit in } \\
\text { parliament, do } \\
\text { they still care } \\
\text { about the } \\
\text { interests of the } \\
\text { people? }\end{array}$ & 0 & 64.6 & 30.8 & 4.6 & 2.4000 & .58095 & 35.4 \\
\hline
\end{tabular}

The highest response of question 10 (In your opinion, after the party members sit in parliament, do they still care about the interests of the people?.) was Less Care with $64.6 \%$ and the weight was $35.4 \%$ indicates that the respondents mentioned that the Islamic political parties care about the interest of the people.

Table 6. Corruption Case Carried out by Islamic Political Parties Cadres Influence Your Choice of the Party

\begin{tabular}{|l|c|c|c|c|c|c|c|}
\hline \multicolumn{1}{|c|}{$\mathrm{N}=65$} & No Effect & $\begin{array}{c}\text { Less } \\
\text { Influential } \\
(2)\end{array}$ & $\begin{array}{c}\text { Take } \\
\text { Effect } \\
(3)\end{array}$ & $\begin{array}{c}\text { Very } \\
\text { Influential } \\
(4)\end{array}$ & Mean & SD & Weight \\
\hline $\begin{array}{l}\text { Does the } \\
\text { corruption case } \\
\text { carried out by }\end{array}$ & 10.8 & 15.4 & 50.8 & 23.1 & 2.8615 & .89925 & 73.9 \\
$\begin{array}{l}\text { Islamic party } \\
\text { cadres influence } \\
\text { your choice of } \\
\text { the party? }\end{array}$ & & & & & & & \\
\hline
\end{tabular}

The highest response of question 11 (Does the corruption case carried out by Islamic party cadres influence your choice of the party?.) was Take Effect with 50.8\% and the weight was $73.9 \%$ indicates that the respondents mentioned that corruption case made by the Islamic political parties elites influences respondents' choice in the general election.

Table 7. Representatives of Islamic Political Parties more Concerned with Personal Interests

\begin{tabular}{|l|c|c|c|c|c|c|c|}
\hline \multicolumn{1}{|c|}{$\mathrm{N}=65$} & $\begin{array}{c}\text { Not } \\
\text { Concerned } \\
(1)\end{array}$ & $\begin{array}{c}\text { Less } \\
\text { Concerned } \\
(2)\end{array}$ & $\begin{array}{c}\text { Concerned } \\
(3)\end{array}$ & $\begin{array}{c}\text { Very } \\
\text { Concerned } \\
(4)\end{array}$ & Mean & SD & Weight \\
\hline $\begin{array}{l}\text { In your opinion, } \\
\text { are the represen- } \\
\text { tatives of Islamic } \\
\text { political parties } \\
\text { more concerned } \\
\text { with personal } \\
\text { interests? }\end{array}$ & 16.9 & 36.9 & 44.6 & 1.5 & 2.3077 & .76899 & 46.1 \\
\hline
\end{tabular}

The highest response of question 12 (In your opinion, are the representatives of Islamic political parties in House of Representatives more concerned with personal interests?) was 
Concerned with $44.6 \%$ and the weight was $46.1 \%$. This indicates that the Islamic political elites in the House of Representatives more concerned with their personal interests than public interests.

Table 8. Percentages and Rank of Each of Peoples' Perception on Islamic

\begin{tabular}{|c|c|c|c|c|c|c|c|}
\hline$\dot{\mathbf{z}}$ & Students' Perception & 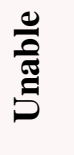 & 点 & $\frac{0}{2}$ & $>\frac{0}{\frac{0}{0}}$ & $\sum^{\tilde{E}}$ & \% \\
\hline 1. & $\begin{array}{l}\text { Islamic political parties are able to } \\
\text { fulfill their promises during } 2014 \\
\text { campaign. }\end{array}$ & 7.7 & 67.7 & 24.6 & 0 & 2.1692 & .54684 \\
\hline 2. & $\begin{array}{l}\text { Islamic political parties are able to } \\
\text { implement their function in fulfilling } \\
\text { the Muslims' aspiration. }\end{array}$ & 7.7 & 44.6 & 43.1 & 4.6 & 2.4462 & .70779 \\
\hline 3. & $\begin{array}{l}\text { Islamic political parties are able to } \\
\text { improve peoples' welfare. }\end{array}$ & 3.1 & 53.8 & 35.4 & 7.7 & 2.4769 & .68711 \\
\hline 4. & $\begin{array}{l}\text { Islamic political parties are able to } \\
\text { build national development. }\end{array}$ & 1.5 & 46.2 & 43.1 & 9.2 & 2.6000 & .68007 \\
\hline 5. & $\begin{array}{l}\text { Islamic political parties are able to } \\
\text { create good cadre. }\end{array}$ & 0 & 55.4 & 32.3 & 12.3 & 2.5692 & .70643 \\
\hline 6. & $\begin{array}{l}\text { Islamic political parties are able to } \\
\text { strengthen political system in } \\
\text { Indonesia. }\end{array}$ & 3.1 & 29.2 & 50.8 & 16.9 & 2.8154 & .74775 \\
\hline 7. & $\begin{array}{l}\text { Islamic political parties are able to } \\
\text { strengthen democratic system in } \\
\text { Indonesia. }\end{array}$ & 3.1 & 30.8 & 50.8 & 15.4 & 2.7846 & .73935 \\
\hline 8. & $\begin{array}{l}\text { Islamic political parties are able to } \\
\text { lead their cadres well. }\end{array}$ & 0 & 36.9 & 52.3 & 10.8 & 2.7385 & .64413 \\
\hline 9. & $\begin{array}{l}\text { Islamic political party cadres who } \\
\text { occupy position in the government are } \\
\text { able to improve party's performance. }\end{array}$ & 3.1 & 46.2 & 44.6 & 6.2 & 2.5385 & .66325 \\
\hline 10. & $\begin{array}{l}\text { Islamic political parties are able to } \\
\text { improve people economic growth. }\end{array}$ & 4.6 & 35.4 & 44.6 & 15.4 & 2.7077 & .78508 \\
\hline 11. & $\begin{array}{l}\text { Islamic political parties which support } \\
\text { government are able to clean } \\
\text { government. }\end{array}$ & 3.1 & 33.8 & 47.7 & 15.4 & 2.7538 & .75064 \\
\hline 12. & $\begin{array}{l}\text { Islamic political parties are able to do } \\
\text { good regeneration. }\end{array}$ & 3.1 & 44.6 & 41.5 & 10.8 & 2.6000 & .72457 \\
\hline 13. & $\begin{array}{l}\text { Islamic political parties which elected } \\
\text { in } 2014 \text { general election are able to } \\
\text { implement role and ideal function as } \\
\text { political parties. }\end{array}$ & 0 & 61.5 & 32.3 & 6.2 & 2.4462 & .61316 \\
\hline 14. & $\begin{array}{l}\text { Islamic political parties are able to } \\
\text { control government performance. }\end{array}$ & 1.5 & 50.8 & 44.6 & 3.1 & 2.4923 & .58957 \\
\hline 15. & $\begin{array}{l}\text { Islamic political parties are able to put } \\
\text { their cadres in legislative body well. }\end{array}$ & 0 & 50.8 & 47.7 & 1.5 & 2.5077 & .53394 \\
\hline 16. & $\begin{array}{l}\text { Islamic political parties are able to } \\
\text { maintain their relation to their voters } \\
\text { (constituents). }\end{array}$ & 4.6 & 49.2 & 40.0 & 6.2 & 2.4769 & .68711 \\
\hline 17. & $\begin{array}{l}\text { Islamic political parties are able to } \\
\text { separate prioritized aspiration to do. }\end{array}$ & 1.5 & 52.3 & 40.0 & 4.6 & 2.7846 & 2.49682 \\
\hline
\end{tabular}

Source: Own results 
The highest response of statement number 1 (Islamic political parties are able to fulfill their promises during 2014 campaign.) was Less Capable with 67.7\%. The highest response for statement number 2 (Islamic political parties are able to implement their function in fulfilling the Muslims' aspiration.) was Less Capable with 44.6\%. The highest response for statement number 3 "Islamic political parties are able to improve peoples' welfare," was Less Capable with 53.8\%. The highest response for statement number 4 (Islamic political parties are able to build national development.) was Less Capable with $46.2 \%$. The highest response for statement number 5 (Islamic political parties are able to create good cadre. ) was Less Capable 55.4\%. The highest response for statement number 6 (Islamic political parties are able to strengthen political system in Indonesia.) was Able with $50.8 \%$. The highest response for statement number 7 (Islamic political parties are able to strengthen democratic system in Indonesia.) was Able with 50.8\%. The highest response for statement number 8 (Islamic political parties are able to lead their cadres well.) was Able with 52.3\%. The highest response for the statement number 9 (Islamic political party cadres who occupy position in the government are able to improve party's performance.) was Able with 44.6\%. The highest response for the statement number 10 (Islamic political parties are able to improve people economic growth..) was Able with $44.6 \%$. The highest response for the statement number 11 (Islamic political parties which support government are able to clean government.) was Able with $47.7 \%$. The highest response for the statement number 12 (Islamic political parties are able to do good regeneration.) was Able with $41.5 \%$. The highest response for the statement number 13 (Islamic political parties which elected in 2014 general election are able to implement role and ideal function as political parties.) was Less Capable with $61.5 \%$. The highest response for the statement number 14 (Islamic political parties are able to control government performance.) was Less Capable with $58.8 \%$. The highest response for the statement number 15 (Islamic political parties are able to put their cadres in legislative body well.) was Able with 50.8\%. The highest response for the statement number 16 (Islamic political parties are able to maintain their relation to their voters (constituents). Less Capable with 69.2\%. The highest response for statement number 17 (Islamic political parties are able to separate prioritized aspiration to do.) was Able with 52.3\%.

Table 9. Percentages and Rank of Each of Peoples' Perception on Islamic Political Party Practices

\begin{tabular}{|c|c|c|c|c|c|c|c|}
\hline$\dot{\mathbf{z}}$ & Students' Perception & $\begin{array}{l}\stackrel{0}{0} \\
\stackrel{+}{0} \\
\stackrel{0}{0}\end{array}$ & $\frac{\frac{n}{0}}{\frac{0}{0}}$ & $\stackrel{\circ}{\circ}$ & $\begin{array}{l}\overline{\overline{0}} \\
\stackrel{3}{=} \\
\stackrel{0}{\circ}\end{array}$ & 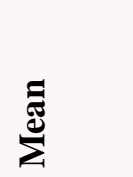 & के \\
\hline 1. & $\begin{array}{l}\text { Islamic political parties do money } \\
\text { politics during campaign. }\end{array}$ & 18.5 & 52.3 & 27.7 & 1.5 & 2.1231 & .71824 \\
\hline 2. & $\begin{array}{l}\text { Islamic political parties do } \\
\text { transparency. }\end{array}$ & 6.2 & 61.5 & 32.3 & 0 & 2.2615 & .56670 \\
\hline 3. & $\begin{array}{l}\text { Islamic political parties have done } \\
\text { well political education to society. }\end{array}$ & 3.1 & 56.9 & 36.9 & 3.1 & 2.4000 & .60725 \\
\hline 4. & $\begin{array}{l}\text { Islamic political parties have carried } \\
\text { out tiered cadres }\end{array}$ & 4.6 & 50.8 & 40.0 & 4.6 & 2.4462 & .66216 \\
\hline
\end{tabular}

Source: Own results

The highest response of statement number 1 (Islamic political parties do money politics during campaign.) was Do Less with 52.3\%. The highest response for statement number 2 (Islamic political parties do transparency.) was Do Less with 61.5\%. The highest response 
for statement number 3 "Islamic political parties have done well political education to society." was 56.9 with $37.1 \%$. The highest response for statement number 4 (Islamic political parties have carried out tiered cadres) was Do Less with $50.8 \%$.

Table 10. Percentages and Rank of Each of Peoples' Perception on Islamic Political Party Practices

\begin{tabular}{|c|c|c|c|c|c|c|c|}
\hline$\dot{z}$ & Students' Perception & 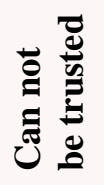 & 竞 & 窇 & ${ }^{2}$ & $\sum_{\Sigma}^{\bar{E}}$ & के \\
\hline 1. & $\begin{array}{l}\text { Promises from Islamic political } \\
\text { parties can still be trusted. }\end{array}$ & 4.6 & 44.6 & 44.6 & 6.2 & 2.5231 & .68711 \\
\hline 2. & $\begin{array}{l}\text { I believe Islamic political parties } \\
\text { accommodate people's aspirations. }\end{array}$ & 3.1 & 44.6 & 40.0 & 12.3 & 2.6154 & .74356 \\
\hline 3. & $\begin{array}{l}\text { I believe Islamic political parties do } \\
\text { money politics by distributing cash. }\end{array}$ & 27.7 & 33.8 & 33.8 & 4.6 & 2.1538 & .88795 \\
\hline 4. & $\begin{array}{l}\text { I believe Islamic political parties do } \\
\text { money politics by distributing } \\
\text { goods. }\end{array}$ & 21.5 & 35.4 & 40.0 & 3.1 & 2.2462 & .82974 \\
\hline 5. & $\begin{array}{l}\text { I believe Islamic political parties do } \\
\text { money politics by distributing } \\
\text { services. }\end{array}$ & 12.3 & 41.5 & 38.5 & 7.7 & 2.4154 & .80801 \\
\hline
\end{tabular}

Source: Own results

The highest response of statement number 1 (Promises from Islamic political parties can still be trusted.) was Less Trustworthy and Can Be Trusted with 44.6\%. The highest response for statement number 2 (I believe Islamic political parties accommodate people's aspirations.) was Less Trustworthy with $44.6 \%$. The highest response for statement number 3 (I believe Islamic political parties do money politics by distributing cash.) was Less Trustworthy and Can Be Trusted with 33.8\%. The highest response for statement number 4 (I believe Islamic political parties do money politics by distributing goods.) was Can Be Trusted with $40.0 \%$. The highest response for statement number 5 (I believe Islamic political parties do money politics by distributing services.) was Less Trustworthy with $38.5 \%$.

\section{What is Your Perception About the Performance of Islamic Political Parties in Indonesia Contemporary Politics Today?}

The informants show their perception on the performance of Islamic political parties in Indonesia political practice today. To show this, some informants gave a wide variety of invaluable comments as stated in Table 11.

Table 11. Participants' perception on the performance of Islamic Political Parties in Indonesia

\begin{tabular}{ll}
\hline Informant 1 & $\begin{array}{l}\text { The performance of Islamic political parties, namely there is public } \\
\text { dissatisfaction with the performance of political parties, especially Islamic } \\
\text { voter-based political parties. }\end{array}$ \\
\hline Informant 2 & $\begin{array}{l}\text { In my opinion, the performance of Islamic political parties is quite } \\
\text { reliable, it can be said to be satisfying. We can see in the event } 212 \text { / } \\
\text { reunion } 212 \text { where the people present at the event were from Islamic } \\
\text { political parties, but they did not include their political parties at the } 212\end{array}$ \\
\hline
\end{tabular}




\begin{tabular}{|c|c|}
\hline & reunion, purely based on their conscience. \\
\hline Informant 3 & $\begin{array}{l}\text { The current performance of Islamic political parties is that Islamic } \\
\text { political parties have experienced competition in Indonesian development, } \\
\text { there is no significant difference between Islamic political parties and not } \\
\text { Islamic political parties. }\end{array}$ \\
\hline Informant 4 & $\begin{array}{l}\text { The performance of Islamic political parties has now begun to diminish } \\
\text { from its position, meaning that Islamic political parties have deviated } \\
\text { from their tracks. }\end{array}$ \\
\hline Informant 5 & $\begin{array}{l}\text { Islamic parties have been increasingly secular where religion is no longer } \\
\text { the main factor that influences public choice in elections. }\end{array}$ \\
\hline Informant 6 & $\begin{array}{l}\text { The Islamic Party has worked well through its programs to help the } \\
\text { community, channel people's aspirations especially in the field of religion. }\end{array}$ \\
\hline Informant 7 & $\begin{array}{l}\text { In my opinion, the performance of Islamic political parties today must be } \\
\text { further enhanced because Islamic political parties in development in } \\
\text { Indonesia have not been too prominent. }\end{array}$ \\
\hline Informant 10 & $\begin{array}{l}\text { Many cadres of political parties are entangled in corruption cases handled } \\
\text { by the Corruption Eradication Commission and politicians are only selfish } \\
\text { not the interests of the community. }\end{array}$ \\
\hline Informant 11 & $\begin{array}{l}\text { The performance of Islamic political parties is good but some Islamic } \\
\text { political elites still abuse their positions. }\end{array}$ \\
\hline Informant 12 & $\begin{array}{l}\text { In my opinion, the performance of Islamic political parties has not had } \\
\text { much impact on the wider community, so political parties with nationalist } \\
\text { ideology are not much different from political parties with Islamic } \\
\text { ideology. }\end{array}$ \\
\hline Informant 13 & $\begin{array}{l}\text { The current performance of Islamic political parties is quite satisfying, } \\
\text { Islamic political parties strongly uphold Islamic law in terms of politics. }\end{array}$ \\
\hline Informant 14 & $\begin{array}{l}\text { In my opinion, the performance of existing Islamic political parties has } \\
\text { carried out their duties responsibly, only the pros and cons between party } \\
\text { leaders and the community still occur. }\end{array}$ \\
\hline Informant 15 & $\begin{array}{l}\text { The performance of Islamic-based political parties in the past few years } \\
\text { has voiced the Islamic Shari'a, but there are other elements that have } \\
\text { become their objectives, for example by overthrowing opponents through } \\
\text { religion. }\end{array}$ \\
\hline Informant 16 & $\begin{array}{l}\text { The performance of Islamic political parties has not been as optimal as } \\
\text { expected by the ummah. }\end{array}$ \\
\hline Informant 17 & Islamic political parties have not worked well. \\
\hline Informant 18 & $\begin{array}{l}\text { The performance of Islamic political parties has not been satisfactory and } \\
\text { can be said to be rather disappointing because many political party cadres } \\
\text { are caught in corruption cases handled by the Corruption Eradication } \\
\text { Commission. }\end{array}$ \\
\hline
\end{tabular}




\begin{tabular}{ll}
\hline Informant 19 & The performance of Islamic political parties is quite satisfying. \\
\hline Informant 20 & In my opinion the performance of Islamic political parties is quite good. \\
\hline Informant 21 & $\begin{array}{l}\text { Islamic political parties cannot yet become the mainstream of political } \\
\text { parties in Indonesia. }\end{array}$ \\
\hline Informant 22 & $\begin{array}{l}\text { In my opinion, Islamic political parties are only mascots and they cannot } \\
\text { give good performance. }\end{array}$ \\
\hline Informant 23 & $\begin{array}{l}\text { In my opinion, Islamic political parties now place more emphasis on how } \\
\text { to produce leaders who are fair, competent, and not corrupt because } \\
\text { leaders who are from Islamic political parties tend to be more trustworthy. }\end{array}$ \\
\hline
\end{tabular}

One way that the Islamic political party voters gave the rational perception through the question which asked: "What is your perception towards performance of Islamic political parties in Indonesia today?" Based on the data from the informants, There were two of them responded that the Islamic political parties in Indonesia political practice today has good performance (informant 2, 6, and 20) and all other informants mentioned that the performance of Islamic political parties in Indonesia today is low. This is because some of party elites are entangled in corruption cases handled by the Corruption Eradication Commission. Islamic parties and their elites tend to deviate from their vision; Islamic political parties have deviated from their tracks (informant 4), some Islamic political elites still abuse their positions (informant 11), and the performance of Islamic political parties has not been as optimal as expected by their voters (informant 17), and so on.

Most participants strongly believed that Islamic political party voters mentioned that Islamic political parties which participated in 2014 legislative election could not fulfill their voters' interest. Where, there is public dissatisfaction with the low performance of Islamic political parties. Lots of Islamic parties and Islamic political elites showed low performance and the Islamic parties and their elites have deviated from their tracks. They did not fulfill their promises during election campaign. Therefore, there are many Islamic political party cadres are caught in corruption cases handled by the Corruption Eradication Commission.

\section{CONCLUSION}

The present study concludes that the performance of Islamic political parties in Indonesia contemporary politics is still low and the Islamic political party voters are unsatisfactory on the Islamic political parties and their political elites. The participants of the present study strongly believed that Islamic political parties which competed in 2014 legislative election could not fulfill their voters' interest. The Islamic political party elites showed low performance and they could not fulfill their promises to their constituents during election campaign and some of the Islamic political cadres did corruption. Further studies in a wide variety of issues with Islamic political parties and their elites in Indonesia political practices are recommended. The implication of this study is that the political party elites, especially the elites from Islamic political parties need to enhance their performance and to fulfill their promises in their campaign to build Indonesia. 


\section{REFERENCES}

Argenti, Gili \& Rifai, Maulana. (2015). Islam Politik Era Refomasi Pergulatan Ideologi Partai Politik Islam Antara Formalis dan Subtansi. Jurnal ilmiah Solusi, Vol. 1 No. 4 Desember 2014 - Februari 2015, pp. 7-19.

Daftar Parpol Peserta Pemilu 2009. From https://nasional.kompas.com, retrieved on 26 January 2019.

Fajri, Isnaini Nurul. (2018). Sikap Masyarakat terhadap Partai Politik Islam: Studi Kasus Kelurahan Korpri Jaya, Kecamatan Sukarame, Kota Bandar Lampung. Unpublished Thesis. Fakultas Ushuluddin dan Studi Agama Universitas Islam Negeri (UIN) Raden Intan Lampung.

Grafik Hasil Pemilu 2014 - Nasional. www.aswandi.com. From http://aswandi.or.id/2014/05/13/grafik-hasil-pemilu-2014/, 26 January 2019.

Hamdan, Yusuf. (2003). Aktualisasi Politik Islam Indonesia: Belajar dari Perolehan Suara Partai Islam dalam Pemilu. Unisba, Volume XIX No. 1 Januari - Maret 2003 : 33 - 47

Kilicdaroglu, Kerem. (2015). The Success and Failure of Islamic parties in Indonesia and Turkey. The Midwest Political Science Association meeting, April 16- 19, 2015, Chicago, pp. $1-30$.

Miichi, Ken. (2015). Democratization and 'Failure' of Islamic Parties in Indonesia. In Southeast Asian Muslims in the Era of Globalization. Japan International Cooperation Agency Research Institute 2015.

Mikail, Kiki. (2015). Pemilu dan Partai Politik di Indonesia: Menanti Kebangkitan Partai Politik Islam di Tahun 2019. Tamaddun, Vol. XV, No. 1/Januari - Juni 2015, pp. $107-$ 148.

Political Map of the Republic of Indonesia. From https://www.nationsonline.org/oneworld/map/indonesia_map2.htm, 29 January 2019.

Porter, Donald J. (2005). Managing Politics and Islam in Indonesia. London: Taylor \& Francis.

Pratama, Andika. (2018). Mengapa Partai Politik Islam Tidak Pernah Menang. Merah Putih.com. from https://merahputih.com/post/read/mengapa-partai-islam-tak-pernahmenang, 26 January 2019.

Tanuwidjaya, Sunny. (2010). Political Islam and Islamic Parties in Indonesia: Critically Assessing the Evidence of Islam's Political Decline. Contemporary Southeast Asia, Vol. 32, No. 1 (2010), pp. 29-49.

Tomsa, Dirk. (2012). Moderating Islamism in Indonesia: Tracing Patterns, of Party Change in the Prosperous Justice Party. Political Research Quarterly, 65(3), p. 486-498.

Weda, Sukardi. (2015). Politik dan Rekayasa Bahasa. Makassar: Media Qita Foundation.

Woischnik, Jan \& Müller, Philipp. (2013). Islamic Parties and Democracy in Indonesia: Insights from the World's Largest Muslim Country. KAS International Reports $10 / 2013$.

Woodwards, Mark. (2008). Indonesia's Religious Political Parties: Democratic Consolidation and Security in Post-New Order Indonesia. Asian Security, vol. 4, no. 1, 2008, pp. 41-60. 